\title{
Health of health care professionals
}

Health care professionals are most negligent as far as their own health is concerned. They are exposed to high risk of various infections and also become victims of lifestyle diseases due to their stressful schedules and high degree of professional responsibility. This editorial focuses on issues related to some of these risks and possible ways and means on how to overcome these risks [Table 1].

The medical fraternity has always been focused on curing and controlling disease for mankind. The art and science of practicing of medicine has evolved itself to its present state, which aims at "protecting from disease and promoting positive health". WHO defines "Health is a state of complete physical, mental and socially being and not merely an absence of disease or infirmity". ${ }^{[1]}$ Good health is aimed at leading a socially and economically productive life. In simple terms our health is influenced by - the air we breathe, the water we drink, the food we eat, the way we think and the society in which we live.

It is time now for providers of 'Health care service' to look at their own health. The family of Health care professionals consists of mainly medical doctors, nurses, paramedical staff and support function staff like hospital maintenance staff, laundry staff, ambulance staff and waste-handling staff.

Health care professionals are exposed to variety of dangers like infections, cuts and needle stick injuries, exposure to

Table 1: Risk of infection for health care professionals

\begin{tabular}{|c|c|c|}
\hline $\begin{array}{l}\text { Type of infection } \\
\text { vehicle }\end{array}$ & Causative organisms & Transmission \\
\hline $\begin{array}{l}\text { Gastroenteric dog } \\
\text { vomitus }\end{array}$ & Enterobacteria, e.g. & Faeces and / or \\
\hline infections & Salmonella, Shigella spp: & \\
\hline & Helminths & \\
\hline Respiratory infections & $\begin{array}{l}\text { Mycobacterium } \\
\text { tuberculosis, measles } \\
\text { virus, streptococcus } \\
\text { pneumonia }\end{array}$ & $\begin{array}{l}\text { Inhaled secretions, } \\
\text { Saliva }\end{array}$ \\
\hline Ocular infection & Herpes virus & Eye secretions \\
\hline Skin infection & Streptococcus spp. & Pus \\
\hline Anthrax & Bacillus anthraces & Skin secretions \\
\hline $\begin{array}{l}\text { Acquired immuno } \\
\text { deficiency syndrome }\end{array}$ & $\begin{array}{l}\text { Human immuno } \\
\text { deficiency virus }\end{array}$ & Blood, body fluids \\
\hline Septicemia & Staphylococcus ssp. & Blood \\
\hline Bacteraemia & $\begin{array}{l}\text { Coagulase-negative, } \\
\text { Staphylococcus ssp. } \\
\text { Staphy aureus, enterobacter }\end{array}$ & Blood \\
\hline Viral hepatitis A & Hepatitis A virus & Faeces \\
\hline Viral hepatitis $B$ and $C$ & Hepatitis $B$ and $C$ viruses & Blood and body fluids \\
\hline
\end{tabular}

Source: WHO Publications: Safe management of waste from health care activities anesthetic gases, radiations, dermatitis causing substances, vaccines and serums and experiences severe stress while treating high risk VIP patients. Most doctors go through a busy schedule day after day and hardly have time for their own lifestyle management. This type of sedentary working life leads to obesity, also makes it prone for hypertension, diabetes and CAD. Their busy stressful life, lack of regular exercise, addictions like smoking and alcoholintake are common and adversely affect their fitness in long term. It also leaves very less quality time to spend with their families, deprives them of sound sleep and participation in social events.

Most of the paramedical staff is exposed to dangers to infection and repetitive strain injuries (mainly lower back ache) due to patient-lifting and transportation, long-standing duties and bad work postures.

It is abundantly clear from the above table that Health care professionals can acquire infection from the patients during the course of the treatment. Most significantly blood forms one of the important media through which they can get dreaded infections like HIV, hepatitis - B and hepatitis - C. Now the issue of coping with direct factors, which cause disease and others like stress and lifestyle diseases in health care professionals. Following standard precautions at the work place can minimize the direct risks.

\section{ESSENTIALS OF STANDARD PRECAUTION TO BE USED IN THE CARE OF ALL PATIENTS}

\section{Protective and preventive vaccinations}

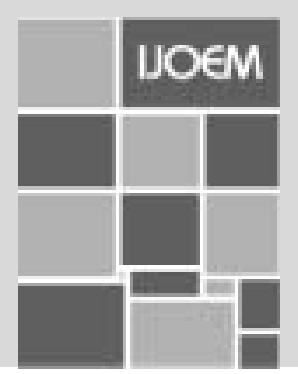


Since there is high rate of needle stick injuries among health care professionals, they must get themselves immunized against viral hepatitis-B. It is advisable to also get immunized against typhoid, hepatitis -A, measles and tetanus. This will be effective in reducing the burden of disease amongst health care professionals. ${ }^{[2]}$

\section{Hand washing}

- Wash hands after touching blood, body fluid, secretions, excretions and contaminated items, whether or not gloves are worn. Wash hands immediately after gloves are removed, between patient contacts.

- Use a plain soap for routine hand-washing.

- Use an antimicrobial agent for specific circumstances.

\section{Gloves}

- Wear gloves when touching blood, body fluids, secretions, excretions and contaminated items. Put on clean gloves just before touching mucous membranes and non-intact skin.

\section{Mask, eye protection, face shield}

- Wear a mask and eye protection or a face shield during procedures and patient care. generate splashes activities that are likely to or sprays of blood, body fluids, secretions and excretions.

\section{Gown}

- Wear a gown during procedure and patient-care activities that are likely to generate splashes or sprays of blood, body, fluids, secretions and excretions.

\section{Patient-care equipment}

- Ensure that reusable equipment is not used for care of another patient until it has been cleaned and reprocessed appropriately.

\section{Environmental control}

- Ensure that the hospital has adequate procedures for the routine care, cleaning and disinfection of environmental surface.

\section{Linen}

- Handle used-linen, solid with blood, body fluid, secretions, excretions in a manner that prevents skin and mucous membrane exposures and that avoids transfer of microorganisms to other patient and environment.

\section{Occupational health and blood borne pathogens}

- Take care to prevent injuries when using needles, scalpels and other sharp instruments or devices.

- Use ventilation device as an alternative to mouth-to-mouth resuscitation method.

\section{Place of care of the patient}

- Place a patient who contaminates the environment or who does not assist in maintaining appropriate hygiene in an isolated (or separate) room. Health care professionals must safeguard their health from above possible infective risks by following safety code during the working life. ${ }^{[2]}$ However they should also look at their individual life style and bring positive changes, which promote healthy living and improves quality of life.

- Develop healthy food habits, which contain fresh fruits, vegetables, salads and sprouts.

- Make their own exercise program of one hour daily. They may use this time for stretching exercise for 15 minutes followed by aerobic exercise like a brisk walk for $45 \mathrm{~min}$ or swimming, tennis, squash or cycling etc. You can also include practice of yoga after getting proper training that may help for a better mental state, concentration and physical agility. Ensure that your exercise should not adversely affect your pre-existing health problems.

- Quit unwanted addictions like smoking, tobacco-chewing and excessive alcohol.

- Unde go health check-up once annually and ensure regular medication and follow-up for any existing health problem. Avoid self-medication.

- Manage your stress by sharing, seeking support from family and peers, rest, relaxation and holiday. If need be, seek help of a professional counselor.

- Take help of an ergonomic expert to design your consulting room, sitting comfortand lighting to reduce repetitive strain and posture related musculo-skeletal disorders. Training can be sought for proper technique of lifting and transporting patients.

- Involve yourself in community service activity.

\section{REFERENCES}

1. Park's Text book of Preventive and social medicine. Park K, editor. $16^{\text {th }}$ ed. 2000. p. 556.

2. Safe management of wastes from health - care activities. Pruss A, Giroult E, Rushbrook P, editor. WHO Publication: Geneva; 1999.

\section{G. K. Kulkarni}

Editor - IJOEM, Indian Association of Occupational Health - India E-mail: editor@ijoem.com 